\title{
AOR
}

Selected Papers of \#AoIR2019:

The $20^{\text {th }}$ Annual Conference of the Association of Internet Researchers Brisbane, Australia / 2-5 October 2019

\section{THE RETURN OF MEDIEVAL SOCIETY - CONTROL, SURVEILLANCE AND NEO-FEUDALISM IN THE AGE OF THE INTERNET}

\author{
Jakob Linaa Jensen \\ Danish School of Media and Journalism
}

\begin{abstract}
:
In this paper the medieval period is used as a prism to analyze and contextualize the intersection of mutual surveillance, corporate capitalism and information control. It is claimed that the interplay between big tech companies, nation states' battle for control and citizens' participatory surveillance, for instance exercised through social media, resembles medieval principles of feudalism and tight social control. As such, this is basically a paper discussing power related to the Internet, as it turns 50 years.
\end{abstract}

The main argument is that apparently distinct social phenomena related to the dominance of Internet technologies share the same logics of control, surveillance and power as the feudalism that dominated medieval society. The states and big corporations both compete and cooperate, just like the states and the church in Middle Ages.

In this paper the medieval period is used as a prism to analyze and contextualize the intersection of mutual surveillance, corporate capitalism and information control. It is claimed that the interplay between big tech companies, nation states' battle for control and citizens' participatory surveillance, for instance exercised through social media, resembles medieval principles of feudalism and tight social control. As such, this is basically a paper discussing power related to the Internet, as it turns 50 years.

\section{Neo-medievalism}

The idea of comparing contemporary phenomena to historical epochs is of course not new. The internet, specifically, has been compared to the Victorian age with the invention of the electrical telegraph (Standage, 1998) and more recently Couldry \&

Suggested Citation (APA): Linaa Jensen, J. (2019, October 2-5). The Return of Medieval Society Control Surveillance and Neo-feudalism in the Age of the Internet. Paper presented at AoIR 2019: The $20^{\text {th }}$ Annual Conference of the Association of Internet Researchers. Brisbane, Australia: AolR. Retrieved from http://spir.aoir.org. 
Mejias (2018) has used the term data colonialism in their analysis of big tech companies' similarities with colonial powers in the $18^{\text {th }}$ and $19^{\text {th }}$ century.

In this paper, I use the Middle Ages as a prism to understand the power regime of corporations and states, based on Internet technologies. Although, to my knowledge, this is the first attempt to connect the Internet with medieval epoch, the period has been used as an analytical tool elsewhere. The term neo-medievalism is most notably affiliated with Italian sociologist and philosopher Umberto Eco (1986) who uses the concept to describe a literary movement where figures and texts from medieval times are used in a contemporary context. In a more narrow sense of the word, neomedievalism has also been used in political theory on international relations. Cerny (1998) and Bull (2002: 245-46) characterize the modern, globalized political order as similar to medieval Europe, where different kinds of territorial powers, along with the Church, competed for sovereignty.

\section{Internet technologies as a juggernaut of informational power}

It is a paradox that the Internet, the ultimate symbol of modernity, transparency and enlightenment facilitates logics of enclosure, censorship and social control, similar to dominant principles of medieval society. The Internet is used in the service of democracy and freedom movements around the world, but it is also used by dictatorships to clamp down on activists and opposition. New media technologies liberate and educate but they are also used to narrow our horizons, create informational bubbles and, wilfully or not, make us more ignorant and less aware of worlds unfamiliar to our own.

In Middle Ages only the privileged classes could read and write and thereby were able to control information and exercise power. Today, governments battle for the same kind of control through censorship in Iran and social scoring in China. Western democracies are moving along the same road as big data are used for crime prediction and monitoring the citizens, as for instance in United Kingdom (Hintz, Dencik \& WahlJørgensen (2018). At the same time, the "big five", Microsoft, Apple, Google, Facebook and Amazon, strive for establishing informational silos, keeping the users within their own information environment.

This is not an analysis specifically of corporate capitalism and economic logics based on the Internet that have already been well described by for instance Fuchs (2014), Chandler \& Fuchs (2019) and Zuboff (2019). Rather it is an attempt to connect the information economy and the rise of participatory surveillance, addressing the power mechanisms behind and describe the development through the frame of medieval society.

\section{Three tools of neo-medieval power}

Although I discuss these trends on a macro level, I elaborate on tools by which the neomedieval power is exercised at a micro level. Three examples:

Disinformation. Whether state propaganda, commercial messages or fake news, 
disinformation is systematically spread and used to manipulate scare or control, similar to superstition and religious claims in Middle Ages, aimed at securing and strengthening the existing social order.

Virtual pillories. The pillory was a central feature of medieval cities, intended for shame and social control; you did not want to be there. Social media are often used as modern pillories: people are judged, often without reason or sound claims by the "social media court", long before any formal judicial verdict is reached. The consequences are real: companies live and die based on reviews by public opinion and, even worse, teenagers have committed suicide because of online bullying.

Participatory surveillance. Medieval society was characterised by mutual surveillance in close-knit societies. Later, surveillance was institutionalized and made impersonal, for instance by panoptic technologies (Foucault, 1977). Such technologies were very much based on formal exercise of power by authorities. Today we are returning to medieval logics of mutual surveillance where we all participate in an omnopticon (Jensen, 2007), willingly, through social media and the use of Google. Privacy is sacrificed for convenience.

\section{The new feudalism}

The original free, unregulated Internet has been colonized, marketed and dominated by players like the big five, Apple, Microsoft, Facebook, Google and Amazon, competing for attention, consumption and money. Politicians and states, afraid of loosing power and control, try to censor, control and regulate, for the bad or for the good, employing persuasive discourses of combatting terrorism, protecting citizens and creating a more efficient society.

Therefore attempting broad, social analyses, grounded in a historical understanding of humans and society are of utmost importance. I will argue that the medieval perspective, understanding contemporary digital, social media-savvy society through metaphors and concepts from medieval society, is fruitful in order to investigate the social and political challenges facing us as the Internet turns 50 years. The main argument is that apparently distinct social phenomena related to the dominance of Internet technologies share the same logics of control, surveillance and power as the feudalism that dominated medieval society. The states and big corporations both compete and cooperate, just like the states and the church in Middle Ages.

The paper is based on my coming book on the Medieval Internet. The paper summarizes the main points and invite conference delegates for a discussion of the neo-feudalism of the information economy.

\section{References}

Bull, H. (2002). The Anarchical Society: A Study of Order in World Politics, 3rd edn. Basingstoke: Palgrave. First published by London: Macmillan, 1977. 
Cerny, P. G. (1998). "Neomedievalism, civil war and the new security dilemma:

Globalisation as durable disorder". Civil wars, 1(1), pp. 36-64.

Chandler, D., \& Fuchs, C. (2019). Digital Objects, Digital Subjects. London: University of Westminster Press.

Couldry, N., \& Mejias, U. A. (2018). Data Colonialism: Rethinking Big Data's Relation to the Contemporary Subject. Television \& New Media.

https://doi.org/10.1177/1527476418796632

Eco, U. (1986). "Dreaming of the Middle Ages," in Travels in Hyperreality, transl. by W. Weaver. NY: Harcourt Brace, 1986, pp. 61-72.

Foucault, M. (1977). Discipline and Punish. New York: Vintage Books.

Fuchs, C. (2014). Social media: A critical introduction. London: Sage.

Hintz, A., Dencik, L., \& Wahl-Jorgensen, K. (2018). Digital citizenship in a datafied society. John Wiley \& Sons.

Jensen, J. L. (2007). The internet omnopticon: surveillance or counter-insurgency. In New publics with/out democracy (pp. 351-380). Samfundslitteratur Press/NORDICOM.

Standage, T. (1998). The Victorian Internet: The remarkable story of the telegraph and the nineteenth century's online pioneers. London: Phoenix.

Zuboff, S. (2019). The age of surveillance capitalism: The fight for a human future at the new frontier of power. London: Profile Books. 